\title{
PERUBAHAN INDEX HIJAU DI KELURAHAN MOODU KECAMATAN KOTA TIMUR KOTA GORONTALO Change Of Green Index In Kelurahan Moodu Kecamatan Kota Timur Of Gorontalo City
}

\author{
Sri Sutarni Arifin ${ }^{1}$, Muhammad Rijal Syukri ${ }^{2}$ \\ ${ }^{1,2}$ Teknik Arsitektur Universitas Negeri Gorontalo, Indonesia \\ Email Korespondensi: sutarniung@gmail.com
}

DOI: http://dx.doi.org/10.31314/jsig.v1i2.182

\begin{abstract}
Increased development in urban areas has resulted in a decrease in the quality of the environment so it is necessary to study the green per capita index to find out the number of green space requirements and analyze changes in green area within 5 years. This research is quantitative by using the ArcGIS Application through the Geographic Information System to calculate the green area and calculate the green index (green index) using mathematical formulas. The results showed that the green index per capita in 2013 was $15.30 \mathrm{~m} 2$ which increased in 2018 by $16.22 \mathrm{~m} 2$. Nevertheless, this condition is not in accordance with the studies that have been carried out previously, namely the green index standard of $20 \mathrm{~m} 2$ per capita.
\end{abstract}

Keywords: green index, green area, environment, cities

\begin{abstract}
Abstrak - Peningkatan pembangunan pada wilayah perkotaan mengakibatkan terjadinya penurunan kualitas lingkungan sehingga perlu dilakukan kajian tentang index hijau per kapita untuk mengetahui jumlah kebutuhan ruang hijau serta menganalisis perubahan luas area hijau dalam kurun waktu 5 tahun. Penelitian ini bersifat kuantitatif dengan menggunakan Aplikasi ArcGIS melalui Sistem Informasi Geografis untuk menghitung luas area hijau serta menghitung index hijau (green index) menggunakan rumus matematika. Hasil penelitian menunjukkan bahwa green index per kapita pada tahun 2013 adalah $15,30 \mathrm{~m} 2$ mengalami peningkatan pada tahun 2018 sebesar 16,22 m2. Meskipun demikian, kondisi ini belum sesuai dengan kajian yang telah dilakukan sebelumnya yaitu standar green index 20 m2 per kapita.
\end{abstract}

Kata kunci: index hijau, area hijau, lingkungan, perkotaan 


\section{PENDAHULUAN}

Wilayah perkotaan merupakan kawasan dengan tingkat pembangunan yang cukup tinggi disertai dengan peningkatan jumlah penduduk yang cukup cepat. Hal ini menimbulkan penurunan kualitas lingkungan perkotaan yang diakibatkan oleh rendahnya kualitas air tanah, tingginya polusi udara dan kebisingan diperkotaan. Tingginya frekuensi banjir di perkotaan juga diakibatkan karena terganggunya sistem tata air karena terbatasnya daerah resapan air dan tingginya volume air permukaan.

Kebutuhan akan Ruang Terbuka Hijau akan terus meningkat seiring dengan bertambahnya jumlah penduduk di suatu wilayah. Oleh karena itu kajian ini disusun untuk mengetahui kebutuhan luas Ruang Terbuka Hijau jenis taman di Kota Gorontalo sebagai salah satu wilayah perkotaan dan juga ibukota Provinsi Gorontalo.

Menurut Stanners dan Bourdeau (1995), masyarakat harus memiliki akses ke Ruang Hijau Perkotaan dalam jarak 15 menit berjalan kaki atau sekitar $900-1.000$ meter. Hal ini sejalan dengan Bjork, et al (2008) yang menyatakan bahwa jarak ke ruang hijau umumnya dilihat sebagai faktor yang paling penting yang terkait dengan penggunaanya, semakin dekat ruang hijau ke lokasi permukiman semakin banyak digunakan. Sementara itu, Coles and Bussey (2000) menyatakan bahwa jarak 300-400 meter sebagai ambang batas terhadap akses ke ruang hijau, setelah itu penggunaannya mulai menurun.

Ruang hijau kota terdiri atas taman kota besar, hutan kota, ladang hijau, pohon di pinggir jalan, hingga ruang hijau pribadi seperti taman pekarangan, kebun atap, dinding pohon dan hijau domestik. Ruang hijau perkotaan tidak selalu termasuk hijau, juga termasuk area biru seperti zona perairan/sungai dan danau yang mendukung pertumbuhan hijau (Cvejić et al., 2015).

Berbeda dengan kajian tersebut, saat ini di Kota Gorontalo, Ruang Terbuka Hijau yang ada belum menyebar secara merata di seluruh wilayah kecamatan. Oleh karena itu disusun penelitian ini yang bertujuan untuk mengetahui jumlah kebutuhan Area Hijau di wilayah penelitian berdasarkan jumlah penduduk dan untuk mengetahui perubahan luas area hijau dalam kurun waktu 5 tahun.

\section{METODE DAN DATA}

Penelitian ini bersifat deskriptif dengan menggunakan metode kuantitatif. Penelitian dilaksanakan di Kelurahan Moodu Kec. Kota Timur Kota Gorontalo. Pemilihan lokasi didasarkan pada alasan bahwa wilayah ini merupakan salah satu kawasan perkotaan dengan tingkat pembangunan cukup cepat dan terdapat Ruang Terbuka Hijau terbesar di Kota Gorontalo yang dapat diakses oleh masyarakat. Metode pengumpulan data meliputi studi literatur, pengumpulan data penduduk, dan data luas area hijau hasil interprestasi citra. Citra yang digunakan adalah hasil perekaman tahun 2013 dan tahun 2018 yang bertujuan untuk membandingkan area hijau pada lokasi penelitian sebelum dan setelah adanya ruang terbuka hijau. Analisis data dilakukan melakukan analisis spasial menggunakan aplikasi Sistem Informasi Geografis (SIG) untuk memetakan sebaran area hijau dan menghitung luasannya. Hasil analisis tersebut selanjutnya di hitung dengan menggunakan rumus :

$$
\text { Green Index }=\sum_{i=1}^{n} G \div \sum_{i=1}^{n} P i
$$

Dimana $\mathrm{G}$ adalah ruang hijau dalam meter persegi dan Pi adalah populasi dalam unit ruang

\section{HASIL DAN PEMBAHASAN}

Area hijau di Kelurahan Moodu Kec. Kota Timur Kota Gorontalo pada tahun 2013 seluas 65.342,76 meter persegi atau sekitar 0,043 persen dari total luas wilayah Kelurahan Moodu yaitu $1,53 \mathrm{~km} 2$ atau $153.000 .000 \mathrm{~m} 2$ pada tahun 2013. Sedangkan tahun 2018 luas area hijau $70.811,92 \mathrm{~m} 2$ atau sekitar 0,046 persen dari luas wilayah. Luas area hijau mengalami peningkatan sekitar 0,04 persen atau seluas $5.469,16 \mathrm{~m} 2$. Data tersebut menunjukkan bahwa peningkatan luas area hijau sekitar 1.093,83 $\mathrm{m} 2$ setiap tahunnya selama rentang waktu 5 tahun. Hasil perhitungan Green Index pada lokasi penelitian berdasarkan hasil analisis menggunakan Sistem Informasi Geografis adalah sebagai berikut: 
Tabel 1. Green Index di Kelurahan Moodu Kec. Kota Timur Kota Gorontalo

\begin{tabular}{cccc}
\hline Tahun & $\begin{array}{c}\text { Area Hijau } \\
\left(\mathrm{m}^{2}\right)\end{array}$ & $\begin{array}{c}\text { Populasi } \\
\text { (jiwa) }\end{array}$ & Green Index \\
\hline 2013 & $65.342,76$ & 4.272 & 15,30 \\
\hline 2018 & $70.811,92$ & 4.365 & 16,22 \\
\hline
\end{tabular}

Berdasarkan Pedoman Penghijauan Perkotaan WHO (2014) dalam Anguluri (2017), menyatakan bahwa standar untuk penghijauan di perkotaan adalah $20 \mathrm{~m} 2$ per kapita. Mengacu pada hal tersebut maka hasil perhitungan green index pada wilayah penelitian menunjukkan bahwa pada tahun 2013 GI sebesar 15,30 m2 dan tahun 2018 16,22 m2. Jumlah ini belum sesuai dengan standar yang ada yaitu $20 \mathrm{~m} 2$ per kapita.
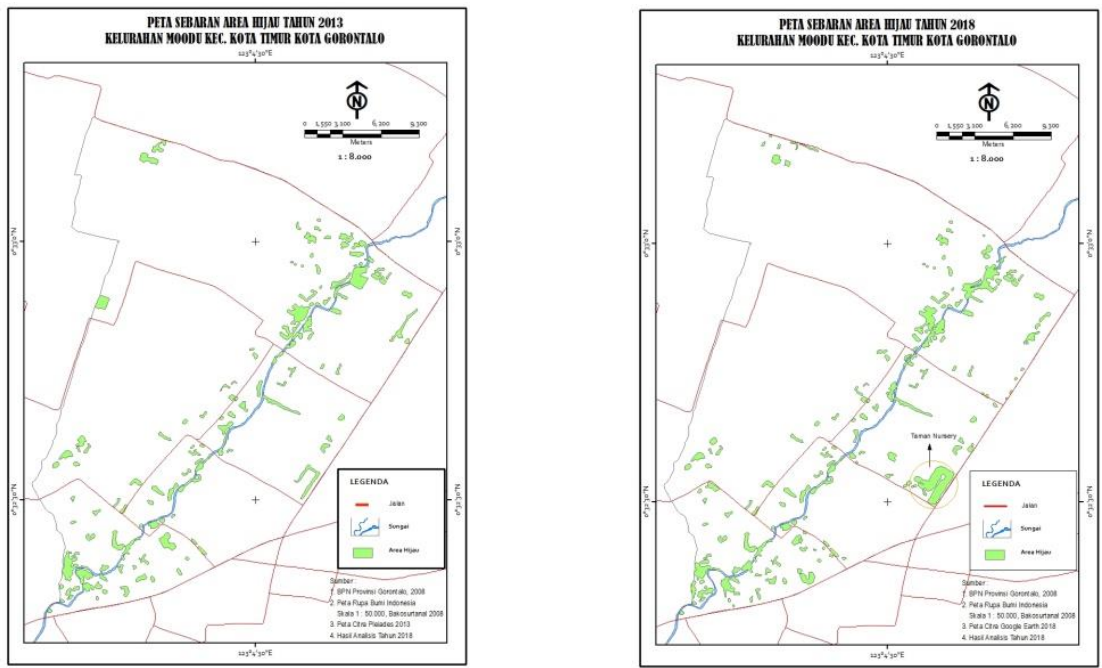

Gambar 1. Peta Sebaran Area Hijau di Kelurahan Moodu Tahun 2013 dan Tahun 2018

Berdasarkan gambar tersebut di atas, dapat dilihat sebaran area hijau berada pada pola yang sama meskipun jumlah luasan mengalami peningkatan dalam kurun waktu 5 tahun. Peningkatan luasan area hijau jelas terlihat pada area lokasi Taman Nursery yang mengalami peningkatan jumlah vegetasi (area hijau) pada tahun 2018 yang sebelumnya pada tahun 2013 belum ada.

\section{KESIMPULAN}

Berdasarkan hasil kajian yang dilakukan pada wilayah penelitian di Kelurahan Moodu Kecamatan Kota Timur Kota Gorontalo menunjukkan bahwa green index per kapita pada tahun 2013 adalah 15,30 m2 mengalami peningkatan pada tahun 2018 sebesar 16,22 m2. Hal ini menunjukkan terjadinya peningkatan luas area hijau pada wilayah penelitian sehingga meskipun jumlah penduduk meningkat dalam kurun waktu 5 tahun namun green index tetap mengalami peningkatan.

\section{DAFTAR PUSTAKA}

Coles, R.W., Bussey, S.C., 2000. Urban forest landscapes in the UK-progressing the social agenda. Landscape Urban Plan 52, 181-188.

Cvejić, R., Eler, K., Pintar, M., Železnikar, Š., Haase, D., Kabisch, N., \& Michael Strohbach, 2015. A Typology Of Urban Green Spaces, Ecosystem Services Provisioning Services And Demands Vol. 7.

Ramesh Anguluri, Priya Narayanan, 2017. Role of Green Space in Urban Planning: Outlook towards smart cities. Urban Forestry \& Urban Greening 11, 432-438. doi:10.1016/j.ufug.2017.04.007

Stanners, D., Bourdeau, P., 1995. The urban environment. In: Stanners, D., Bourdeau, P. (Eds.), Europe's Environment: The Dobris Assessment. European Environment Agency, Copenhagen, pp. 261-296. 